\title{
An econometric analysis of Shanghai office rents
}

By

Qiulin $\mathrm{Ke}^{*}$ and Michael White**

*School of the Built Environment, Nottingham Trent University, Burton Street, Nottingham, UK, NG1 4BU

Tel: 00441158482381

Email: qiulin.ke@ntu.ac.uk

**School of the Built Environment, Sir William Arrol Building

Heriot-Watt University

Edinburgh, UK, EH14 4AS

Tel: 00441314514659

Email: m.j.white@hw.ac.uk 


\title{
An econometric analysis of Shanghai office rents
}

\begin{abstract}
The modern commercial office market in Shanghai emerged with China's economic reform and open door policy in the 1980s and grew rapidly at the beginning of 1990s, with increasing demand for office space from foreign and domestic occupiers. Though total real estate investment is skewed towards residential property, office investment has grown by $23 \%$ per annual in terms of value and by $24 \%$ per annum in terms of completed floor space from 1995 to 2007. The Shanghai office market is of importance for a number of reasons. First, it is one of the largest office markets in China in terms of square footage and in investment terms. Second, the office market is one of most established ones in China and attracts most attention from policy makers, investors, practitioners and academia. However, so far there is little empirical research on the Shanghai office market. This paper will use econometric modelling techniques to investigate office rent determination of the CBD in the central Puxi area, Shanghai, over the period 1991 2007. Using a reduced form modelling specification in an error correction framework based on demand and supply interactions, GDP and office stock are found to significantly affect office rental performance in the Shanghai market in the long run. The model also shows that the office market adjusts to equilibrium. This model is then extended to test the impact of foreign direct investment, real interest rates, and vacancy rates on rental determination.
\end{abstract}

Keywords: Shanghai office market, rental performance, error correction 


\section{Introduction}

Intense competition for a limited pool of desirable assets, combined until recently with yield compression in most global markets, has resulted in real estate funds broadening their geographic search for opportunities. Investors of all types keen on attaining higher returns while increasing their portfolio diversification have been driving the globalization of commercial real estate investment to unprecedented levels in recent years. Diversification in both geography and property sectors has become a vital strategy for global investors seeking to spread their risks while growing their portfolios.

China has become one of the major recipients of foreign direct investment. By 2007, more than 100 foreign countries and regions had investments in some 30,000 local projects in China. International investors are eager to exploit the potential of investing in China, particularly in Shanghai, the finance, commerce and economic centre of China.

Sustained economic growth in Shanghai continues to spur office demand. Financial and professional services firms are expanding swiftly. For example, in 2007 there were another 30 regional head offices of multinational companies, 15 investment companies and 34 foreign research and development centres being located in Shanghai, creating demand for high-grade office space. As early as 1995, 38\% of total foreign investment in Shanghai was property related (Li et al., 1999). The strong demand for office space and the positive outlook for the Shanghai office market have drawn a massive inflow of foreign investment into the Shanghai real estate market rising from US\$0.52 billion in 2005 to US\$ 1.01 billion in 2007. This occurred despite the fact that Central Government departments jointly issued two documents in 2006 to strengthen control over foreign investment in real estate acquisition and development. It stated that for total investment of more than US\$10 million, the registered capital of a real estate foreign investment enterprise should not be lower than $50 \%$ of the total investment (previously 40\%) and if the registered capital of a foreign investment enterprise is less than $35 \%$ of the total investment, loans are not allowed to be taken out. The regulations raised the threshold for foreign investors who entered the Chinese property market. However, the Central Government's ongoing macro-control measures did not dampen investor optimism. The China Property Law passed in the first quarter of 2006 boosted investor confidence in long-term property investment since the law clarified the status of property rights upon the expiration of the initial term of land leases.

Shanghai's property market has expanded rapidly since the 1990s. However there is no empirical study on office rental movements in the city. This new research is undertaken against such a background and is therefore particularly important for investors, practitioners, and policy makers domestically and internationally.

This paper is structured as follows: section 2 provides an overview of the rent modelling literature. This is followed, in section 3, by a description of the evolution of Shanghai office market. Section 4 outlines the methodology and describes the data. The empirical findings are discussed in section 5 and conclusions are drawn for future research in section 6. 


\section{Literature Review}

The analysis of commercial office market rental movements itself has undergone significant developments in the last two decades. Unlike other areas of economics and even in comparison to housing economics, analysis of commercial real estate rents has been constrained by insufficient data. These data constraints manifest themselves in a number of ways. The first, and most obvious, has been the shortness of time series. In the UK and US, annual data rarely go back beyond 1970 and thus it has only been relatively recently that it has been possible to identify long run relationships (Hendershott et al, 2002a and b, Farrelly and Sanderson 2005, Mouzakis and Richards 2007). In China, time series are significantly shorter, since the property market virtually did not exist before 1980s, the pre-reform era.

The second aspect relates to supply side data. Unbroken time series are usually unavailable and this is also true of the markets in Chinese cities. Researchers are thus limited in how to deal with supply. Either they can restrict their study to cover only the periods when data are available or they can attempt to use interpolation methods to fill gaps in time series observations.

Finally, it is important to note that developments in the analysis of commercial real estate markets have coincided with developments in time series econometric analysis. This is evident in the analyses reviewed below.

Gardiner and Henneberry (1988) examine regional office markets in England. Similar to almost all UK research into commercial real estate rents, they adopt a reduced form modelling approach. In this framework rent is the dependent variable and research has focused on identification of appropriate proxy variables to capture demand and supply side influences.

The authors proxy demand by using lagged as well as current values for gross domestic product (GDP). This can be seen as a way of attempting to account for partial and slow adjustment of real estate market responses to changing economic conditions. It also reflects the uncertainty that users may have about the degree of permanence of changes in demand conditions for their own outputs. This in turn implies their demand for space will lag the demand they experience for their products or services.

Gardiner and Henneberry (1988) write their model as;

$$
R R_{t}=\alpha+\beta_{1} G D P R_{t}+\beta_{2} G D P R_{t-2}+\beta_{3} F S R_{t}+\varepsilon_{t}
$$

where $R R$ is rent, $F S$ refers to floorspace, as a measurement of supply and $\varepsilon$ is the stochastic disturbance. The $R$ suffix to each variable indicates that it is a ratio to the relevant national value of that variable. 
The data used cover the period 1977-1984 and results are presented for each of the eight standard regions of England. The authors find that the supply variable usually has the correct sign, a priori. Current GDP is only significant in one region whilst lagged GDP is almost always significant, although with a negative sign in three cases (two of these are insignificant). As the authors note, the high $\mathrm{R}^{2}$ is odd given the insignificance of explanatory variables in many of the models, indicating the possibility of multicollinearity. The poorest results were found for the North, North West, East and West Midlands with a stronger relationship between rents and explanatory variables found for the South East, South West, East Anglia and Yorkshire and Humberside.

Gardiner and Henneberry's results present an early attempt to analyse regional commercial office markets relating rent to user demand and allow for spatial variation in market performance. The authors' concern for their failure to adequately explain rental movements in more northern regions led them to consider habit-persistence theories and adaptive expectations in rent formation.

Gardiner and Henneberry (1991) develop these ideas. Allowing for slow or partial adjustment in real estate markets, the authors adopt an adaptive expectations approach where changes in the expected demand for space are some function of past differences between actual demand outcomes and the prediction from the previous period. Hence:

$$
D_{t}^{*}-D_{t-1}^{*}=(1-\lambda)\left(D_{t}-D_{t-1}^{*}\right)
$$

where the * superscript indicates an expectation and $\lambda(0 \leq \lambda \leq 1)$ represents a speed of adjustment, the speed at which new information is added or expectations are formed. The higher is $\lambda$, the more slowly do expectations change or new information is incorporated. Given adaptive expectations, rental adjustment may follow a similar path to that described for demand in equation (2) above.

In empirical estimation, the authors use lagged rent as an explanatory variable along with current GDP. They also introduce moving average (MA) terms into some of their models. The general modelling equation takes the following form;

$$
R R_{t}=\alpha+\beta_{1} R R_{t-1}+\beta_{2} R R_{t-2}+\beta_{3} G D P R_{t}+\left(u_{t}-\lambda u_{t-1}\right)
$$

where $\mathrm{u}$ is the disturbance term and the term in parenthesis reflects an MA(1) process. Their regional results indicate a poor fit of the model for the South East, South West and East Anglia. Only the second lag on rents is significant for Yorkshire and Humberside. The model provides a better fit for the North, North West and East Midlands. However GDP is rarely significant in any region and may be correlated with other explanatory variables. Adding MA errors had mixed results, improving the fit for some regions but not others. Results could not reject the hypothesis of a more cautious approach taken by occupiers of offices in more northern regions.

While general auto-regressive moving average modelling has been applied to commercial real estate market analysis (see Gibb et al., 2000), Gardiner and Henneberry (1991) omit 
a supply side variable in (3) above. This may induce bias in their estimates in addition to the potential for multicollinearity. Nevertheless, their idea of habit-persistence is consistent with slow adjustment in real estate markets.

Since their studies were conducted, many single equation models (or reduced form demand-supply equations) have been widely used in the research on office rent determination, for example, in addition to the above, Glascock, et al. (1990) and Sivitanides (1997) for US office markets; Dobson and Goddard (1992), Keogh et al. (1998), Chaplin (2000), Matysiak and Tsolacos (2003) for UK markets, Giussani, et al. (1993), D'Arcy, et al.(1997 and 1999), Mouzakis and Richards (2007, discussed below) for European markets, Chin (2003) and De Wit and Van Dijk (2003), for Southeast Asian markets. It has been argued that single equation estimates are to be preferred in small samples (Davidson and MacKinnon, 1993). In general, this model tries to capture the relationship between economic activity and office rents, based on the assumption of equilibrium between demand and supply.

In US literature, analysis of office rents have often been examined in a multi-equation modelling framework. In these models there is an absorption equation, a construction equation and a rental adjustment equation in which changes in rent are written as a function of differences between equilibrium and actual vacancy rates. Such approaches have been applied to the London office market by Wheaton et al. (1997) and Hendershott et al. (1999). One specific area of interest in these models is the rental adjustment equation. Wheaton et al. (1997) for example, relate rental change to the vacancy rate and the rate of absorption to occupied stock. More generally rental change is written as a function of the difference between the equilibrium and actual vacancy rate.

$$
\left(R_{t}-R_{t-1}\right) / R_{t-1}=\lambda\left(v^{*}-v_{t-1}\right)
$$

Where $\mathrm{R}$ is rent, $\mathrm{v}$ is the vacancy rate, $\mathrm{v}^{*}$ is the equilibrium vacancy rate, and $\lambda$ is the adjustment parameter. This idea was extended by Hendershott $(1995,1996)$ who argued that in the model equilibrium rents were not specified. The model was therefore extended to include deviations from equilibrium rent:

$$
\left(R_{t}-R_{t-1}\right) / R_{t-1}=\lambda\left(v^{*}-v_{t-1}\right)+\beta\left(R_{t} *-R_{t-1}\right)
$$

Where $\mathrm{R}^{*}$ is equilibrium rent and the adjustment parameters are $\lambda$ and $\beta$. These are theoretically not unrelated to the concept of error correction applied in a reduced form modelling framework which is discussed more fully below.

Hendershott et al. (2002a) examine the rental adjustment process in London and Sydney office markets. They apply equations similar to (5) above and test for stationarity and cointegration. Long run vacancy rates of $3.3 \%$ to $7.1 \%$ and $6.4 \%$ to $9.8 \%$ are estimated for London and Sydney respectively. The variation depends upon the format of equation chosen. 
The authors also estimate an error correction mechanism (ECM) formulation, constructing a reduced form model that consists of a long run equilibrium relationship and a short run dynamic model which includes an error correction term. A similar model is estimated in Hendershott, et al. (2002b) focusing on regional retail and office markets in the UK. This paper has a relatively long run of data covering the period 1970-1998 which itself covers two major cycles in UK commercial real estate markets. The authors again examine the time series properties of dependent and independent variables, testing for stationarity and cointegration. A panel model is estimated covering all regions in Great Britain, excluding London which is estimated separately since the responsiveness of rent to demand and supply side variables is statistically significantly different from all other regions. The modelling procedure, whilst relying on reduced form estimation, allows for short run adjustment towards a long run 'equilibrium' path using the error correction mechanism.

Whilst the available data preclude the construction of structural models, common in the US, the authors suggest that the difference between actual and natural vacancy rates in rental adjustment equations make up a large part of the error correction term that links their short run rental equation to the long run 'equilibrium' relationship (see Hendershott et al., (2002b), p62-63 for details).

Demand for space can be written as a function of user demand (E) and rent (R). Thus:

$$
D=\lambda_{0} R^{\lambda_{1}} E^{\lambda_{2}}
$$

Where $\lambda_{1}$ and $\lambda_{2}$ are price and income elasticities respectively. In equilibrium, demand for space will be equal to the total supply of space that is occupied. Hence:

$$
D=(1-v) S U
$$

Where SU is supply of space. Substituting (7) into (6) and taking logs we have:

$$
\ln R=\gamma_{0} \ln \lambda_{0}+\gamma_{1} \ln E+\gamma_{2} \ln S U+\gamma_{2} \ln (1-v)
$$

This long run model without the final term containing the vacancy rate has been used by Hendershott et al. (2002b). Coefficients $\gamma_{1}$ and $\gamma_{2}$ are expected to be positive and negative respectively. Price and income elasticities can be retrieved from (8) since $\lambda_{1}=1 / \gamma_{2}$ and $\lambda_{2}=-\gamma_{1} / \gamma_{2}$. The residual from this relationship is the difference between actual rent and those values estimated by the model. Hence:

$u_{t}=\ln R_{t}-\hat{\gamma_{0}}-\hat{\gamma_{1}} \ln E_{t}-\hat{\gamma_{2}} \ln \left[\left(1-v_{t}\right) S U_{t}\right]$

Where $u_{t}$ is the residual from the long run model. If (8) is a cointegrating relationship comprising individual variables that are integrated of order one, I(1), then the error term will be integrated of order zero, i.e., is stationary, I(0), and an error correction mechanism 
can be constructed using the lagged value of the residual from (8) in a short run dynamic model:

$$
\Delta \ln R_{t}=\phi_{0}+\phi_{1} \Delta \ln E_{t}+\phi_{2} \Delta \ln S U_{t}+\phi_{3} \Delta \ln \left(1-v_{t}\right)+\phi_{4} u_{t-1}
$$

In this model, the change in rents is a function of the change in demand and supply and is also related to the lagged difference between actual and long run rent reflecting market disequilibrium. The coefficient $\phi_{1}$ is expected to be positive while $\phi_{2}$ and $\phi_{3}$ are expected to be negative. The coefficient $\phi_{4}$ is expected to range between 0 and -1 where a 0 value implies no adjustment, -1 implies full adjustment and values within this range of 0 to -1 imply partial adjustment. A value smaller than -1 implies over-adjustment.

Hendershott et al. (2002a) report results (for London offices) for a range on models based upon (8) and (10) above. In general results accord with a priori expectations. The user demand variable (employment), the vacancy rate and the error correction terms are all correctly signed and significant.

In Hendershott et al. (2002b) office demand (as represented by finance and business services employment) and supply variables had the expected signs, although the demand variable for London was statistically insignificant in the long run model. In the short run model, the error correction term was again correctly signed and suggested a relatively slow adjustment to 'equilibrium' after any shock or market imbalance. In relation to the regional markets the authors state that, "[the regions] are driven by fluctuations in demand and supply and by lagged adjustments towards equilibrium. While the timing and intensity of shocks might vary between the North and South, the response of rents to given shocks is not statistically different." (Op Cit., p75) This might imply that there is significant similarity in the performance of non-London regions.

Mouzakis and Richards (2007) provide a comprehensive study of office markets in Europe and extend and develop their analysis which is based upon the same estimation procedure as Hendershott et al. (2002a, b) discussed above. They use output to capture user demand and include a persistence term to capture "pure persistence in the movement of rents, the lagged dependent variable, which can capture pure time delays in the adjustment of pricing to fundamentals." (Op. Cit, p35) They proceed to examine office markets in eleven European cities. For output they use local Gross Value Added (GVA) and for supply they generate a stylised floorspace series which they construct from measurements of the elasticity of change in floorspace with respect to total new space completions over the time period covered by their dataset for each city. They then construct a panel model. In doing this, they conduct panel unit root tests and subsequently test for cointegration. Their results could not reject cointegration and hence they proceed to estimate error correction models. The authors also compare fixed-effects against random-effects models.

Mouzakis and Richards provide a detailed discussion of panel estimation approaches and present results based upon error correction models and also analyse alternative model specifications. Autoregressive distributed lag models (ARDL) are estimated. They 
provide diagnostic statistics for the ECM, ARDL(1) and ARDL(2) models and an ARIMA $(2,1,2)$ specification. Their results suggest that the ECM has higher explanatory power and lower mean absolute error than the other model formulations. The performance of the error correction term for most cities examined is in general in accordance with a priori expectations. The ARIMA model was found to perform worst in predictive tests. Thus it could be argued that the theory-driven model (the ECM) outperformed the more atheoretical ARIMA model.

The more recent econometric techniques described above are particularly useful for explicitly addressing issues of market adjustment and setting this within the appropriate long run setting with a short run dynamic. To do this they rely on the availability of quality time series data. In this paper we apply the techniques described above to an analysis of the Shanghai office market. This is a relatively new and emerging ${ }^{1}$ market and has a relatively short history of office market investment. The objective of this study is to examine the data which have now become available to analyse the behaviour of the market to identify the significant determinants of office rental value in the CBD of the central Puxi area in Shanghai, with the aim to fill the gap in office rent research on this emerging market.

\section{The evolution of commercial office market in Shanghai}

Shanghai is the largest economic centre and important port city in China, covering 6,340 square kilometres and a population of 16 million people. In the 1930s and 1940s, Shanghai was the financial and commercial centre of Far East Asia. From 1949, when the People's Republic of China was founded, to 1978, under the centrally planned economic system and with the aim of industrialization, Shanghai was transformed from a comprehensive service centre into a manufacturing centre. The output of manufacturing industry represented over $50 \%$ of Shanghai's GDP. The service industry ${ }^{2}$ (including transportation, telecommunications, retail, leisure, finance, insurance and real estate) contributed on average $28 \%$ of its GDP.

After economic reform in 1978, Shanghai began to restore its position as the financial, trade and economic centre of China. At the beginning of the 1990s, the Shanghai municipal government adopted a new policy to adjust its industrial structure and prioritized the development of the service sector over manufacturing and agriculture. Subsequently, Shanghai experienced a structural shift and transformation in its economy. In 1999 the service industry overtook manufacturing industry in terms of output, with the former representing $50 \%$ of its GDP and latter 48\%. By 2007, the service industry represented over 52\% of Shanghai's GDP. Within the service sector, finance, insurance and real estate represented $15 \%$ of its GDP.

Figure 1

\footnotetext{
${ }^{1}$ See Keogh and D'Arcy (1994) for a full discussion of property market maturity.

${ }^{2}$ Conventionally, in Chinese Statistics, the agricultural industry is termed the First Industry; manufacturing industry, the Second Industry, and the service industry, as the Tertiary Industry
} 


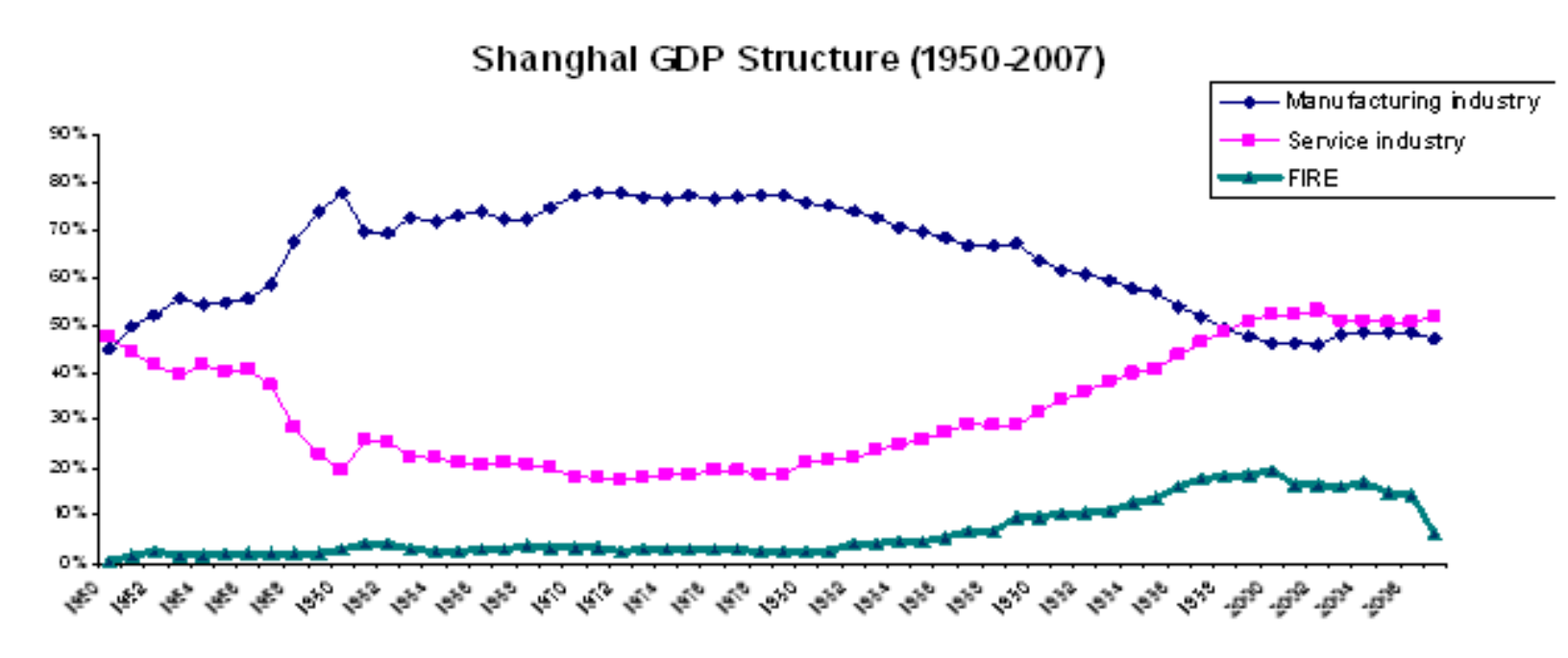

Source: Shanghai Statistics Yearbook

Employment in the service sector represented $41 \%$ of total employment before 2002 . Since then, over 55\% of employees gained employment in the service sector, reflecting economic transformation. Employment in finance, insurance and real estate from 19932007 accounted for $3 \%$ of total employment, but increased by $18 \%$ per annum, faster than other industries (see Figure 2). In 2007, it accounted for $6 \%$ of total employment.

Figure 2



Source: Shanghai Statistics Yearbook

A modern commercial office market emerged in the late 1980s. During this period the property market in China was at a developmental stage and was still part of the planned economy. In 1987, , a piece of state owned land in Shenzhen was put on the market for public auction, symbolizing what could be seen as the beginning of a commercial real estate (land) market in China although private property rights still did not exist. However it was not until the 1990s that the property market began to develop. Laws and regulations concerning the transfer of land use rights and land administration came into 
effect. Large scale office building projects commenced. According to a DTZ report, in 1993, Shanghai had Grade A office stock of 0.12 million s.q.m and by 2007 it had 4.16 million s.q.m. It is estimated that the investment-grade office supply in Shanghai will peak by 2010, with total stock reaching 6.2 million s.q.m (JLL, 2007).

In 1995, investment in the Shanghai office market was worth RMB 8.17 billion (US\$ 1.06 billion), reaching a peak in 1996 with RMB 15.08 billion (US\$1.93 billion), declining thereafter due to the high vacancy rate resulting from overbuilding and a slowdown of foreign investment during the Asian financial crisis (see Figure 3). The oversupply continued to 1998 when the vacancy rate for prime grade offices was $48 \%$ (DTZ, 1998). Office investment bottomed in 2001 with RMB 2.62 billion (US\$ 0.34 billion) and started to pick up thereafter. In 2007 the office investment was RMB15.75 billion (US\$ 2.16 billion), increasing by $93 \%$ in contrast to 1995 . Over 1995-2007, the investment in residential housing accounted for $66 \%$ of total real estate investment, while investment in offices was, on average, $13 \%$.

Figure 3

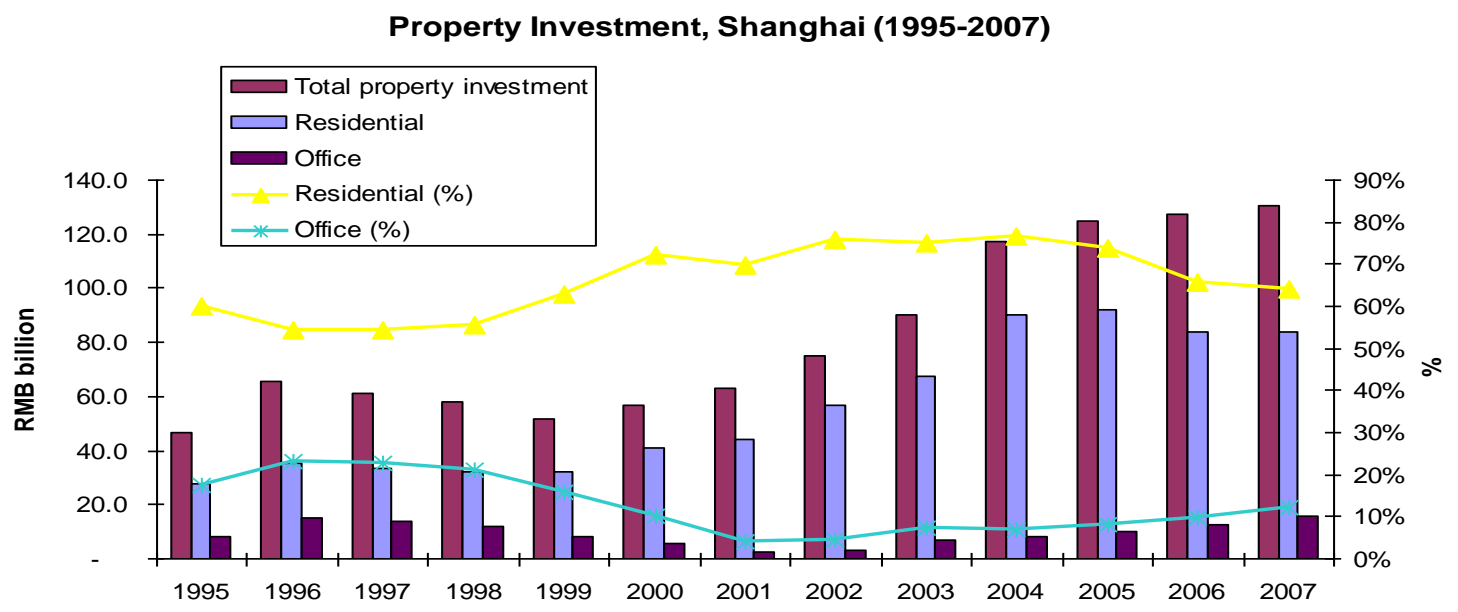

Source: Shanghai Statistics Yearbook

The major users of office space are in the service related sector, especially finance, insurance and real estate service sectors. In Shanghai, a significant proportion of office demand is derived from foreign companies. The restructuring of economic activity has underpinned the exceptionally strong demand for office space in a similar way to the strong and sustained growth that has been experienced despite notable cyclicality.

The fast expanding economy and robust economic outlook for China has been attracting foreign direct investment and Shanghai is a major recipient. In 1990, FDI in Shanghai was only US\$ 0.177 billion (see Figure 4). Since then it has fluctuated but by 2007 stood at US\$ 7.92 billion, representing $11 \%$ of total FDI in China. FDI in real estate has represented on average 14\% of total FDI in Shanghai and was worth US\$1.01 billion in 2007 
Figure 4

Foreign Direct Investment in Shanghai (1990-2007)

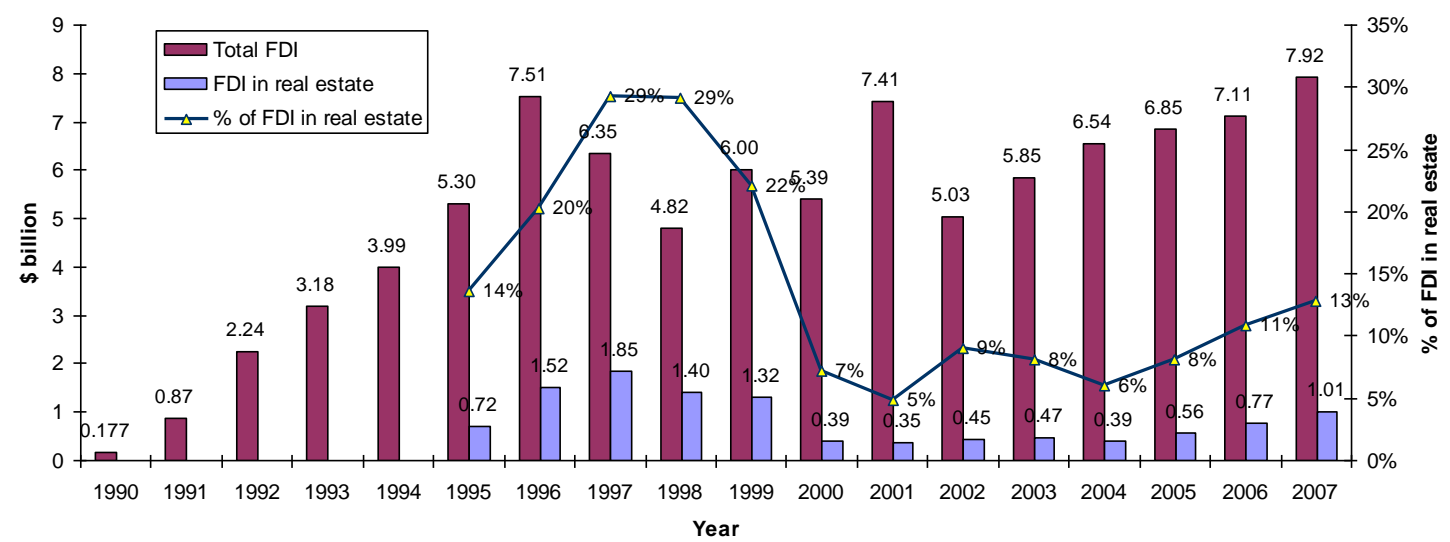

By the end of 2007, approximately 100 multinationals had set up their Greater China or Asia-Pacific headquarters in Shanghai, and more are expected to follow. Multinational companies clustered strongly in downtown CBD locations in central Puxi. In anticipation of China completely opening up its financial services in the next few years as part of its World Trade Organization commitment, foreign commercial banks are aggressively expanding, and competing for market share. Professional services providers such as accounting firms, law firms and investment banking firms are also either opening new offices or find themselves in a hiring spree and requiring more office space.

Shanghai office market is significant in terms of size and volume of investment. The citywide Grade A stock total has risen to 4.16 million sq.m. (DTZ, 2007). In recent years, a clear CBD has emerged, consisting of central Puxi and Little Lujiazui, in Pudong District. Our study here will focus on the office submarket in the central Puxi area. The Shanghai Puxi central office submarket, named after its geographic location on the west bank of River Huangpu to differentiate from Pudong, on the east bank of the river, is located along Nanjing Road West, Huaihai Road and People's Square (see Figure 5), aggregately representing over $60 \%$ of total Grade A office space (DTZ, 2007). Another prime central business district is Lujiazhui CBD in Pudong District, one of the largest Special Economic Development Zones in China. This submarket is not included in our study due to incomplete data. The distribution of Shanghai Grade A office is presented in Figure 5.

Figure 5. Shanghai Grade A office distribution 


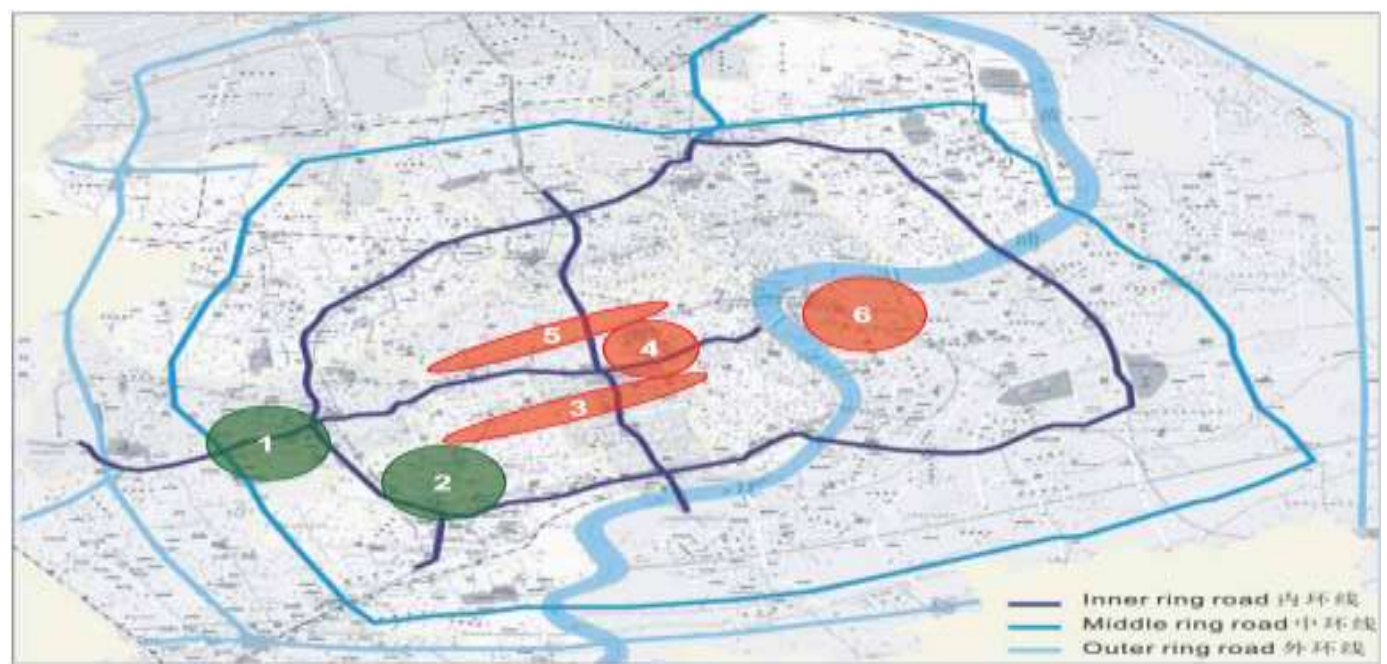

Note: 1-Hongqiao and 2- Xujiahui are second tier business hubs which are excluded in this study. 3Huaihai Road, 4- People's Square and 5- Nanjing Road West are first tier business hubs. 6 is Lujiazui in Pudong (first tier business hub) which is excluded in this study.

Source: (DTZ, Shanghai).

Lease contracts are governed by the Contract Law in China. The lease term varies from 1 to 3 years, with typical lease terms of 2-3 years with the option of renewal. The tenants are responsible for repair and insurance charged by the landlord in the form of service charges. The rent review is undertaken at lease renewal and is based on open market rental value. Assignment /subletting is subject to landlord approval and is generally accepted. Early termination can be achieved only by a break clause. At the end of the lease term, the tenant is responsible for reinstalling the property to its original condition allowing for wear and tear. Rent is paid monthly in advance and usually a 2-3 month rental deposit is required. Rent-free periods are not applicable. As can be seen in Figure 6 below, rents and vacancy rates have exhibited substantial amplitude of fluctuation. Figure 6:

Office Rents and Vacancy Rates 


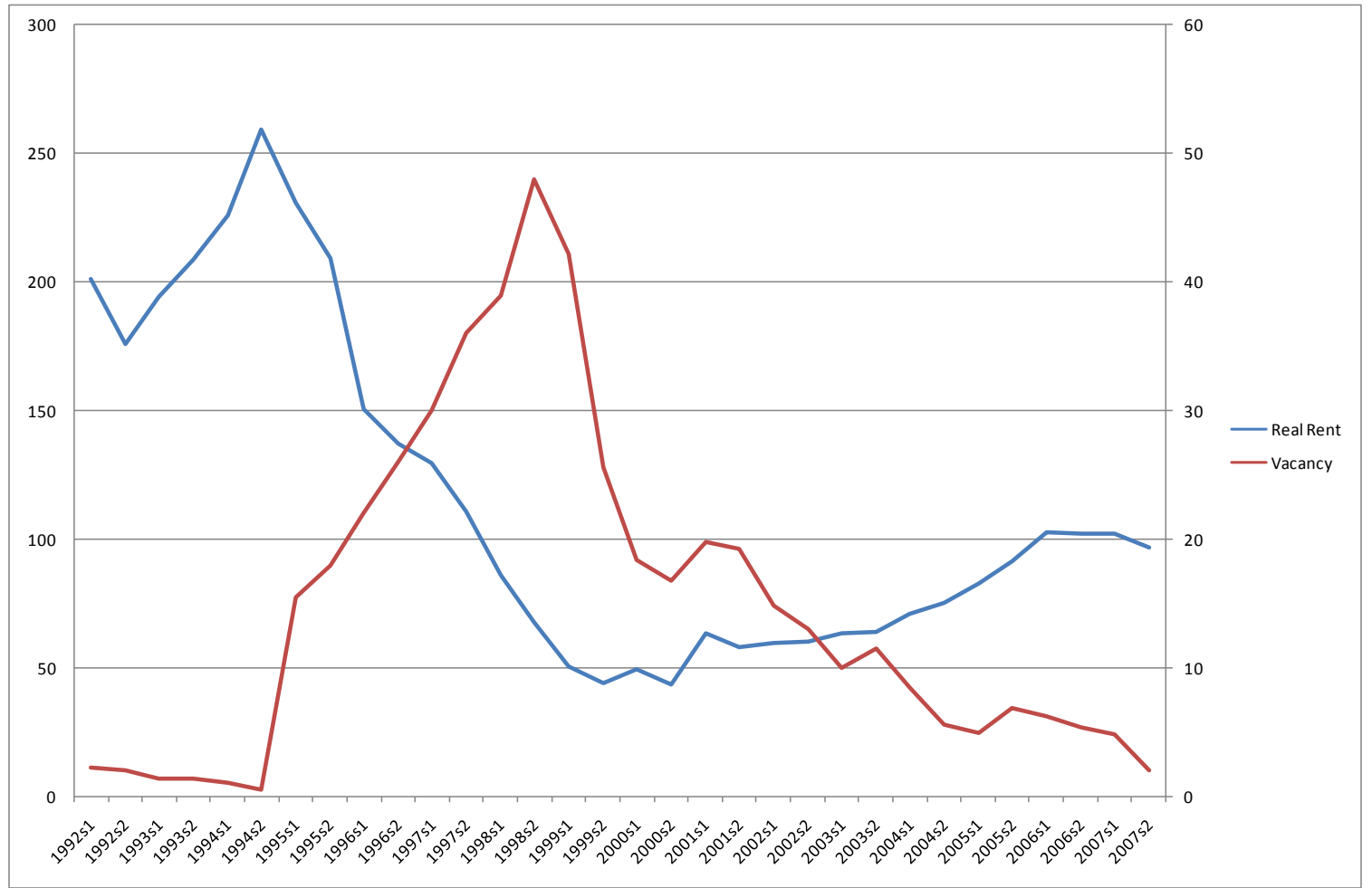

Source: DTZ, Shanghai, China.

In Figure 6, real rents are measured on the left hand scale and the vacancy rate (\%) is measured on the right hand scale. Real rents fall from the mid-1990s as new supply begins to arrive on the market. The vacancy rises from below 1\% in 1994 to $48 \%$ in 1998 following the Asian financial crisis. By 2000, the vacancy rate has fallen below $20 \%$ and real rents begin to show signs of increasing. Even before the start of our dataset, evidence from Li et al. (1999) suggests significant fluctuation in vacancy rates from a high of $45 \%$ in 1986 to a relative low of $9 \%$ in 1988. It is against this relatively volatile background that we attempt to model rental determination.

\section{Data and Methodology}

In this paper, a single equation reduced form model is used to test long run rent performance and an error correction mechanism is used to test for short term adjustment to market imbalance. In its most parsimonious form, rent is written as a function of demand and supply. Here we estimate models in (8) and (10) above. Thus:

$\ln R=\gamma_{0} \ln \lambda_{0}+\gamma_{1} \ln E+\gamma_{2} \ln S U+\gamma_{2} \ln (1-v)+u_{t}$

$\Delta \ln R_{t}=\phi_{0}+\phi_{1} \Delta \ln E_{t}+\phi_{2} \Delta \ln S U_{t}+\phi_{3} \Delta \ln \left(1-v_{t}\right)+\phi_{4} u_{t-1}+\varepsilon_{t}$ 
Where $\left(8^{\prime}\right)$ and $\left(10^{\prime}\right)$ are the long and short run models respectively and the error terms, $u_{t}$ and $\varepsilon_{t}$ are explicitly noted. The stochastic disturbance terms are assumed to have zero mean and constant variance. These equations are estimated with and without the vacancy rate terms. In addition since Shanghai and especially Puxi have received significant amounts of foreign direct investment (FDI), the potential impact of this source of finance on the office market is also explicitly tested. A variable measuring FDI is added to the regression models above.

In the previous studies of office rent determination, the most common indicators on demand side used in the econometric model include GDP and service sector employment (e.g. Hekman, 1985, Guissani et al., 1993, D'Arcy, et al.1997 and 1999, Chin, 2003, De Wit and Van, Dijk, 2003), since office space demand is a derived demand and fluctuates with the local economy and office space is mainly occupied by service sectors. In this paper results are presented for both GDP and employment separately as demand proxies.

The most common variables for office space supply side are office floor stock, vacancy rates, or new construction (e.g. Hekman, 1985, Shilling, et al., 1987, Gardiner and Henneberry, 1988, Hendershott, et al., 1999, Parker, et al. 2003, Chin, 2003, De Wit and Van, Dijk, 2003). Given the restrictions of the available data and based on the existing empirical studies, the stock variable is used as a supply measure. Hence we can rewrite $\left(8^{\prime}\right)$ and $\left(10^{\prime}\right)$ substituting these variables as:

$$
\begin{aligned}
& \ln R=\gamma_{0} \ln \lambda_{0}+\gamma_{1} \ln D+\gamma_{2} \ln \text { Stock }+\gamma_{2} \ln (1-v)+u_{t} \\
& \Delta \ln R_{t}=\phi_{0}+\phi_{1} \Delta \ln D_{t}+\phi_{2} \Delta \ln \text { Stock }_{t}+\phi_{3} \Delta \ln \left(1-v_{t}\right)+\phi_{4} u_{t-1}+\varepsilon_{t}
\end{aligned}
$$

Where the demand variable D represents either employment or GDP, the stock measure is floorspace and (when included) the vacancy rate in the Puxi office submarket used to reflect the supply side. To consider the role of FDI, a variable is added in both the long run and short run models. Further, given the autoregressive nature of rental determination, the lagged difference of rent is added to (12). Finally, the impact of the cost of credit as measured by the real interest rate is also tested.

The major problem in this research on the Shanghai office market is the short-time series and unavailability of quality data. The office data used in this study are collected from DTZ which was the first consultancy firm to collect office market information in mainland China, beginning in 1991. The data used in this study are semi-annual and include the asking rent, vacancy rate, and total office stock in the CBD of the central Puxi area. The non-property variables used such as GDP and service sector employment are adopted from Shanghai Statistics Year Books. GDP and service sector employment are at the municipal level of the whole Shanghai. Employment in service sector is measured as the total number of employees in tertiary industries, inclusive of retail, leisure, transportation, telecommunication, finance, insurance and real estate since the complete set of data of the employees in finance, insurance and real estate back to 1991 is not available. The full time period covered is from the first half of 1991 to the second half of 2007. All data are in real terms where appropriate. 


\section{Results of Analysis}

Prior to estimation of the models above, Augmented Dickey-Fuller unit root tests were undertaken to discover the order of integration of each time series variable used and results were reported in Table 1. The standard regression for this approach is:

$$
\Delta x_{t}=\alpha+\beta_{1} x_{t-1}+\sum_{i=1}^{\rho-1} \delta_{i} \Delta x_{t-i}+\mu_{t}
$$

where the chosen value for $\rho$ is such that $\mu_{t}$ will be a white noise error term. The $t$ statistic on $\beta_{1}$ is compared with the critical values found in Fuller (1976). When only the lagged value of $\mathrm{x}$ is present, the test is referred to as a Dickey-Fuller (DF) test. When lagged difference terms are added, the resulting test is an Augmented Dickey-Fuller (ADF) test. An alternative approach to adding lagged values of the dependent variable has been suggested by Phillips (1987) and extended by Perron (1988) and Phillips and Perron (1988). They suggest adding a non-parametric correction to the $t$-test statistic. This accounts for autocorrelation that may be present.

Table 1. Unit Root Tests

\begin{tabular}{lcc}
\hline & ADF & PP \\
\hline Rent & $-11.138^{* * *}(\mathrm{I}(2))$ & $-4.302^{* * *}$ \\
GDP & $-33.404^{* * *}$ & $-33.376^{* * *}$ \\
Stock & $-3.082^{* *}$ & $-3.071^{* *}$ \\
Services Employment & $-4.700^{* * *}$ & $-10.768^{* * *}$ \\
Vacancy Rate & $-5.583^{* * *}$ & $-5.883^{* * *}$ \\
FDI & $-4.693^{* * *}(\mathrm{I}(0))$ & $-9.766^{* * *}(\mathrm{I}(0))$ \\
Real Interest Rate & $-3.507 * *(\mathrm{I}(0))$ & $-7.546^{* * *}$ \\
\hline
\end{tabular}

Note: All variables are I(1) unless stated otherwise. *, ** and *** stand for the $10 \%, 5 \%$ and $1 \%$ significance levels respectively.

Most of the variables used in estimation are stationary in first differences with the exception of FDI which is stationary in levels. The result for the rent variable and the real interest rate differ between the tests used. Rent is I(2) on the ADF test and I(1) on the PP test while the real interest rate is $\mathrm{I}(0)$ on the ADF test and $\mathrm{I}(1)$ on the PP test. We now proceed to estimate equation (11), first without the vacancy rate.

Table 2: Long Run Model

Sample: 1991S1 2007S2

Included observations: 34

\begin{tabular}{ccccc}
\hline \hline Variable & Coefficient & Std. Error & t-Statistic & Prob. \\
\hline \hline
\end{tabular}




\begin{tabular}{lrlrl}
\multicolumn{1}{c}{ C } & 10.39497 & 0.379063 & 27.42284 & 0.0000 \\
Gross Domestic Product & 1.227739 & 0.170354 & 7.206992 & 0.0000 \\
\multicolumn{1}{c}{ Stock } & -0.845184 & 0.072137 & -11.71636 & 0.0000 \\
\hline \hline R-squared & 0.884876 & Mean dependent var & 4.634215 \\
Adjusted R-squared & 0.877448 & S.D. dependent var & 0.549696 \\
S.E. of regression & 0.192434 & Akaike info criterion & -0.374028 \\
Sum squared resid & 1.147958 & Schwarz criterion & -0.239349 \\
Log likelihood & 9.358474 & F-statistic & 119.1371 \\
Durbin-Watson stat & 1.502866 & Prob(F-statistic) & 0.000000 \\
\hline
\end{tabular}

The table 2 presents the results from the long run model. Both demand (GDP) and supply (Stock) variables have the expected signs and are statistically significant at the $1 \%$ level. The adjusted $\mathrm{R}^{2}$ is reasonably high, and the model explains over $87 \%$ of the variation in rent. The DW statistic indicates that autocorrelation is present however this should not be a problem so long as cointegration is present ${ }^{3}$. The implied 'price' elasticity of space demand is -1.183 and the 'income' elasticity is 1.453 . Thus space demand is both price and income elastic. The price elasticity is higher and the income elasticity slightly lower than in the similar Hendershott et al. (2002a) model. The model in table 2 is then tested for cointegration following Johansen (1991). The results of the tests are presented in Table 3 below. The tests indicate the presence of one cointegrating equation from the model in equation (11). Following this, the estimated residual from the long run model is then used in its lagged form as the error correction term in the short run dynamic equation. The results for this model are presented below in Table 4.

Table 3: Johansen Cointegration Tests

Unrestricted Cointegration Rank Test (Trace)

\begin{tabular}{ccccc}
\hline \hline $\begin{array}{c}\text { Hypothesized } \\
\text { No. of CE(s) }\end{array}$ & Eigenvalue & $\begin{array}{c}\text { Trace } \\
\text { Statistic }\end{array}$ & $\begin{array}{c}0.05 \\
\text { Critical Value }\end{array}$ & Prob.** \\
\hline \hline None * & 0.504368 & 29.82524 & 29.79707 & 0.0496 \\
At most 1 & 0.195360 & 8.065680 & 15.49471 & 0.4584 \\
At most 2 & 0.041919 & 1.327524 & 3.841466 & 0.2492 \\
\hline \hline
\end{tabular}

Trace test indicates 1 cointegrating eqn(s) at the 0.05 level

* denotes rejection of the hypothesis at the 0.05 level

**MacKinnon-Haug-Michelis (1999) p-values

Unrestricted Cointegration Rank Test (Maximum Eigenvalue)

\footnotetext{
${ }^{3}$ This might be expected as the model is estimated in levels. We can use the co-integrating regression's residuals in the ECM, so long as they are I(0), even if they are autocorrelated (since the only implication of autocorrelation is that we cannot make firm inferences about the coefficients in the original co-integrating relationship.
} 


\begin{tabular}{ccccc}
$\begin{array}{c}\text { Hypothesized } \\
\text { No. of CE(s) }\end{array}$ & Eigenvalue & $\begin{array}{c}\text { Max-Eigen } \\
\text { Statistic }\end{array}$ & $\begin{array}{c}0.05 \\
\text { Critical Value }\end{array}$ & Prob.** \\
\hline \hline None $*$ & 0.504368 & 21.75956 & 21.13162 & 0.0408 \\
At most 1 & 0.195360 & 6.738156 & 14.26460 & 0.5206 \\
At most 2 & 0.041919 & 1.327524 & 3.841466 & 0.2492 \\
\hline \hline
\end{tabular}

Max-eigenvalue test indicates 1 cointegrating eqn(s) at the 0.05 level

* denotes rejection of the hypothesis at the 0.05 level

**MacKinnon-Haug-Michelis (1999) p-values

Table 4: Short Run Model

Sample (adjusted): 1991S2 2007S2

Included observations: 33 after adjustments

\begin{tabular}{lrlll}
\hline \hline \multicolumn{1}{c}{ Variable } & Coefficient & Std. Error & t-Statistic & Prob. \\
\hline \hline \multicolumn{1}{c}{ C } & 0.018215 & 0.027692 & 0.657742 & 0.5159 \\
$\quad$ & & & \\
$\quad$ Gross Domestic & 0.149744 & 0.178562 & 0.838608 & 0.4085 \\
$\quad \begin{array}{llll}\Delta \text { Product } \\
\text { Stock }\end{array}$ & -0.486212 & 0.155581 & -3.125130 & 0.0040 \\
Error Correction Term & -0.328592 & 0.135906 & -2.417788 & 0.0221 \\
\hline \hline R-squared & 0.349168 & Mean dependent var & -0.021437 \\
Adjusted R-squared & 0.281840 & S.D. dependent var & 0.146258 \\
S.E. of regression & 0.123945 & Akaike info criterion & -1.224743 \\
Sum squared resid & 0.445509 & Schwarz criterion & -1.043348 \\
Log likelihood & 24.20826 & F-statistic & 5.186113 \\
Durbin-Watson stat & 1.733463 & Prob(F-statistic) & 0.005434 \\
& & & \\
\hline
\end{tabular}

The results for the short run model accord with a priori expectations. All variables have the expected signs, although the demand variable (the change in GDP) is statistically insignificant. The stock variable, capturing supply, is negatively significant as is the error correction term. The error correction coefficient implies slower adjustment to market imbalance in Shanghai than that found for other cities in Europe, for example, an indicated by the findings in Mouzakis and Richards (2007).

Both models in equations 11 and 12 were estimated using services employment as the demand variable. Results are presented in the appendix to the paper in tables A1 and A2. The results are broadly similar to those presented above.

The model (12) was re-estimated to include the lagged change in rent as an explanatory variable, the results from which are shown in table 5. 
Table 5: Short Run Model with Lagged Rental Change

\begin{tabular}{|c|c|c|c|c|}
\hline \multicolumn{5}{|c|}{ Sample (adjusted): 1992S1 2007S2 } \\
\hline \multicolumn{5}{|c|}{ Included observations: 32 after adjustments } \\
\hline & & & \multirow[b]{2}{*}{ t-Statistic } & \\
\hline Variable & Coefficient & Std. Error & & Prob. \\
\hline $\mathrm{C}$ & 0.015755 & 0.029674 & 0.530929 & 0.5998 \\
\hline$\Delta$ Gross Domestic & O 122780 & 0188152 & 0.652605 & 05105 \\
\hline$\Delta$ Stock & -0.407651 & 0.184706 & -2.207022 & 0.0360 \\
\hline $\begin{array}{c}\text { Error Correction } \\
\text { Term }\end{array}$ & -0.344036 & 0.143758 & -2.393160 & 0.0239 \\
\hline $\begin{array}{c}\text { Lagged Rental } \\
\text { Change }(-1)\end{array}$ & 0.160885 & 0.182268 & 0.882686 & 0.3852 \\
\hline R-squared & 0.367357 & \multicolumn{2}{|c|}{ Mean dependent var } & -0.020615 \\
\hline Adjusted R-squared & 0.273632 & \multicolumn{2}{|c|}{ S.D. dependent var } & 0.148521 \\
\hline S.E. of regression & 0.126580 & \multicolumn{2}{|c|}{ Akaike info criterion } & -1.153284 \\
\hline Sum squared resid & 0.432607 & \multicolumn{2}{|c|}{ Schwarz criterion } & -0.924262 \\
\hline Log likelihood & 23.45254 & \multicolumn{2}{|l|}{ F-statistic } & 3.919520 \\
\hline Durbin-Watson stat & 2.120877 & \multicolumn{2}{|l|}{ Prob(F-statistic) } & 0.012327 \\
\hline
\end{tabular}

The addition of the lagged dependent variable as an explanatory variable has not added to the model's explanatory power and the variable itself is clearly statistically insignificant. This differs from other findings in which the lagged dependent variable has often been found to be significant.

Table 6 presents results of equations (11) and (12) including the vacancy rate (Model 1), and also, separately for FDI (Model 2), and real interest rates (Model 3).

Table 6*

\begin{tabular}{|l|c|c|c|}
\hline & Model 1 & Model 2 & Model 3 \\
\hline Long Run Model & \multicolumn{3}{|c|}{} \\
\hline & \multicolumn{3}{|c|}{} \\
\hline Constant & 10.280 & 9.388 & 10.506 \\
& $(24.365)$ & $(11.319)$ & $(25.249)$ \\
\hline Gross Domestic & 1.281 & 1.259 & 1.273 \\
Product & $(5.451)$ & $(6.804)$ & $(7.299)$ \\
\hline Stock & -0.856 & -0.867 & -0.877 \\
& $(-8.814)$ & $(-10.228)$ & $(-11.304)$ \\
\hline$(1-v)$ & -0.045 & & \\
& $(-0.162)$ & & \\
\hline
\end{tabular}




\begin{tabular}{|c|c|c|c|}
\hline $\begin{array}{l}\text { Foreign Direct } \\
\text { Investment }\end{array}$ & & $\begin{array}{c}0.456 \\
(1.973)\end{array}$ & \\
\hline Real Interest Rate & & & $\begin{array}{c}0.066 \\
(1.159) \\
\end{array}$ \\
\hline Adjusted R-squared & 0.866 & 0.835 & 0.875 \\
\hline DW & 1.626 & 1.422 & 1.766 \\
\hline \multicolumn{4}{|l|}{ Short Run Model } \\
\hline Constant & $\begin{array}{c}0.025 \\
(0.865)\end{array}$ & $\begin{array}{c}0.019 \\
(0.542)\end{array}$ & $\begin{array}{c}0.027 \\
(0.931)\end{array}$ \\
\hline $\begin{array}{l}\Delta \text { Gross Domestic } \\
\text { Product }\end{array}$ & $\begin{array}{c}0.236 \\
(1.229)\end{array}$ & $\begin{array}{c}0.124 \\
(0.510)\end{array}$ & $\begin{array}{c}0.099 \\
(0.495)\end{array}$ \\
\hline$\Delta$ Stock & $\begin{array}{c}-0.582 \\
(-3.448) \\
\end{array}$ & $\begin{array}{l}-0.527 \\
(-2.891) \\
\end{array}$ & $\begin{array}{r}-0.536 \\
(-3.292) \\
\end{array}$ \\
\hline$\Delta(1-v)$ & $\begin{array}{c}-0.657 \\
(-1.718) \\
\end{array}$ & & \\
\hline $\begin{array}{l}\Delta \text { Foreign Direct } \\
\text { Investment }\end{array}$ & & $\begin{array}{c}0.077 \\
(0.596)\end{array}$ & \\
\hline$\Delta$ Real Interest Rate & & & $\begin{array}{c}0.054 \\
(1.290)\end{array}$ \\
\hline Error Correction Term & $\begin{array}{c}-0.495 \\
(-2.946) \\
\end{array}$ & $\begin{array}{c}-0.371 \\
(-2.305) \\
\end{array}$ & $\begin{array}{l}-0.313 \\
(-2.025) \\
\end{array}$ \\
\hline Adjusted R-squared & 0.327 & 0.254 & 0.267 \\
\hline DW & 1.598 & 1.694 & 1.704 \\
\hline
\end{tabular}

*t-statistics are in parentheses

Endogeneity of vacancy rates means that we replace the actual vacancy rate with a vacancy rate predicted from an $\mathrm{AR}(1)$ model $^{4}$. More complex AR structures did not improve explanation of the vacancy rate. Adding this vacancy rate term (model 1) has little impact in the long run model. The variable's coefficient is different from that on stock but is statistically insignificant. In the short run model, the vacancy rate term is marginally significant at the $10 \%$ and its coefficient has the expected sign and is 'close' to that on stock. Elasticities for the price elasticity of demand and income elasticity of demand for space are -1.168 and 1.496 respectively. In comparison to the model without vacancy rate in table 4, the error correction term is bigger in absolute terms as are the other coefficients in the model. FDI is found to be significant (model 2) in the long run model at the 5\% level, however it is statistically insignificant in the short run model. As an $\mathrm{I}(0)$ variable it would not enter the long run cointegrating vector and may be weakly

\footnotetext{
${ }^{4}$ This approach has some similarity to work by Voith and Crone (1988) and Grenadier (1995). Hendershott et al. (2002a) also use an $\mathrm{AR}(3)$ process to explain the vacancy rate.
} 
exogenous. Finally the real interest rate is included in model 3. This variable proved to be insignificant in both the short and the long run.

\section{Conclusions}

This research has attempted to use an econometric model to test the relationship between macro economic activity and office rental movement in the central Puxi area, Shanghai over the period of 1991 to 2007 . We estimate simple reduced form models that indicate responses to demand and supply variables that are consistent with theoretical expectations. We explicitly allow for adjustment in the short run model via the inclusion of an error correction term which is correctly signed and statistically significant in all model scenarios tested. Adjustment occurs but more slowly than that implied by results for other major office centres.

However the results should be interpreted with some caution. Specifically we cover seventeen years of data which may be too short to allow accurate identification of a long run. Also this is a period that has seen a new commercial property market develop and it could be characterized as a transitional market. Overbuilding was a key feature of the market whose institutional characteristics and lack of market information may have caused unusual developer behaviour which, in a more mature and transparent market, would have been different. The behaviour of government may also have significantly impacted land supply for specific types of development. As the market develops, its characteristics may be expected to change and this in turn may affect the responsiveness of rent to underlying demand and supply side factors. These reasons point to potential changes in the 'long run' identified in the research above. Indeed, structural change and hence structural breaks in relationships may be experienced, suggesting again that the estimates should be regarded with caution. Nevertheless it has been possible to explicitly consider market adjustment processes in this relatively new and emergent office market and consider the role of key variables of GDP, employment, stock, and vacancy rates. It has also been possible to examine the role played by foreign direct investment all within a modelling approach whose structure is driven not simply by data but by theoretical considerations. However the relatively parsimonious model estimated has been capable of generating reasonable results, a priori, and suggests that a logical market adjustment process is in operation in Puxi, Shanghai. 


\section{References}

Chaplin, R. (2000) Predicting Real Estate Rents: Walking Backwards into the Future, Journal of Property Investment and Finance, 18(3), 352-370

Chin, H. W. (2003), Macro-economic Factors Affecting Office Rental Values in Southeast Asian Cities: The Case of Singapore. Hong Kong, Taipei. Kuala Lumpur and Bangkok, Pacific Rims Real Estate Society Conference, Brisbane, Australia.

D’Arcy, E., McGough, T. and Tsolacos, S. (1997), National Economic Trends, Market Size and City Growth Effects on European Office Rents, Journal of Property Research, 14(4), 297-308.

D'Arcy, E., McGough, T. and Tsolacos, S. (1999), An econometric analysis and forecasts of office rental cycle in the Dublin area', Journal of Property Research, 16(4)309-321.

Davidson, R and MacKinnon, J. G. (1993), Estimation and Inference in Econometrics, New York, Oxford University Press.

De Wit, I. and Van Dijk, R. (2003), The Global Determinants of Direct Office Real Estate Returns', Journal of Real Estate Finance and Economics, 26(1), 27-45.

Dobson, S. and Goddard, J. (1992) The Determinants of Commercial Property Prices and Rents, Bulletin of Economic Research, 44, 301-321.

DTZ (1998), The Property Times, Q4, 1998. www.dtz.com.

DTZ (2007), The Property Times, Q4, 2007. www.dtz.com.

Farrelly, K. and Sanderson, B. (2005) Modelling Regime Shifts in the City of London Office Rent Cycle. Journal of Property Research, 22(4), 325-344.

Fuller, W. A. (1976), Introduction to Statistical Time Series. New York: John Wiley.

Gardiner, C. and Henneberry, J. (1988) The Development of a Simple Regional Office Rent Prediction Model, Journal of Valuation, 7(1), pp.36-52.

Gardiner, C. and Henneberry, J. (1991) Predicting Regional Office Rents Using Habitpersistence Theories, Journal of Property Valuation and Investment, 9(3), 215-226.

Gibb, K., Mackay, D. and White, M. (2000), A Comparative Analysis of Scottish Property Rents, Journal of Property Investment and Finance, 18(3), 332-351.

Glascock, J., Jahanian, L. and Sirmans, C. F. (1990), Analysis of Office Market Rents: Some Empirical Evidence, AREUEA Journal, 18(1), 105-19. 
Grenadier, S. (1995) Local and National Determinants of Office Vacancies. Journal of Urban Economics, 37, 57-71.

Guissani, B., Hsia, M. and Tsolacos, S. (1993) A Comparative Analysis of The Major Determinants of Office Rental Values in Europe. Journal of Property Valuation and Investment, 11(2), 157-173.

Hekman, J. S., (1985), Rental Price Adjustment and Investment in the Office Market, Journal of the American Real Estate and Urban Economics Association, 13, 32-47.

Hendershott, P. H. (1995), Real Effective Rent Determination: Evidence from the Sydney Office Market, Journal of Property Research, 12 (2), 127-35.

Hendershott, P.H. (1996), Rental Adjustment and Valuation in Overbuilt Markets: Evidence from the Sydney Office Market, Journal of Urban Economics, 39, 51-67.

Hendershott, P. H., Lizieri, C. and Matysiak, G. A. (1999), The Workings of the London Office Market, Real Estate Economics, 27(2), 365-387.

Hendershott, P., MacGregor, B. And Tse, R. (2002a), Estimation of the Rental Adjustment Process. Real Estate Economics, 30(2), 165-183

Hendershott, P., MacGregor, B. and White, M. (2002b), Explaining Commercial Rents Using an Error Correction Model with Panel Data. Journal of Real Estate Finance and Economics, 24(1), 59-87.

JLL, (2007), Advance, www.jll.com.

Johansen, S. (1991), Estimation and Hypothesis Testing of integration vectors in Gaussian Vector Autogressive models. Econometrics, 59, 1551-1580.

Keogh, G. and D'Arcy, E. (1994) Market maturity and property market behaviour: a European comparison of mature and emergent markets, Journal of Property Research, $11,215-235$.

Keogh, G., McGough, T. and Tsolacos, S. (1998) Modelling Use, Investment, and Development in the British Office Market, Environment and Planning A, 30, 1409-1427.

Li, L., Tse, R. and Ganesan, S. (1999) Shanghai, in Berry, J. and McGreal, S. (eds) Cities in the Pacific Rim: Planning Systems and Property Markets, E \& FN Spon, London.

Matysiak, G. and Tsolacos, S. (2003), Identifying Short-term Leading Indicators for Real Estate Rental Performance, Journal of Property Investment \& Finance, 21 (3) 212-232.

Mouzakis, F. and Richards, D. (2007) Panel Data Modelling of Prime Office Rents: A Study of 12 Major European Markets. Journal of Property Research, 24(1), 31-53. 
Parker, D., MacFarlane, J., Peng, V. and Murray, J. (2003), Forecasting Property Market Cycles: An Application of the RICS Model to the Sydney CBD Office Market', Journal of Financial Management of Property and Construction, 8(3), 179-191.

Perron, P. (1988) Trends and Random Walks in Macroeconomic Time Series: Further Evidence from a New Approach, Journal of Economic Dynamics and Control, 12, 13611401.

Phillips, P. (1987), Time Series Regression with a Unit Root, Econometrica, 55, 277301.

Phillips, P. and Perron, P. (1988), Testing for a Unit Root in Time Series Regressions, Biometrika, 75, 335-46.

Shilling, J.D., Sirmans, C. F. and Corgel, J. B. (1987) Price Adjustment Process for Rental Office Space, Journal of Urban Economics, 22, 90-100.

Sivitanides, P. S. (1997), The Rent Adjustment Process and the Structural Vacancy Rate in the Commercial Real Estate Market, Journal of Real Estate Research, 13(2), 195-209.

Voith, r. and Crone, T. (1988) National Vacancy Rates and the Persistence of Shocks in the US Office Markets. Journal of the American Real Estate and Urban Economics Association, 16, 437-458.

Wheaton, W.C., Torto, R.G. and Evans, P. (1997) The Cyclic Behavior of the Greater London Office Market, The Journal of Real Estate Finance and Economics, 15(1), 77-92. 
Appendix

Table A1: $\quad$ Long Run Model

Sample: 1991S1 2007S2

Included observations: 34

\begin{tabular}{lclcr}
\hline \hline \multicolumn{1}{c}{ Variable } & Coefficient & Std. Error & t-Statistic & Prob. \\
\hline \hline \multicolumn{1}{c}{ C } & 0.245306 & 1.116719 & 0.219666 & 0.8276 \\
$\quad$ Eervices & 3.378660 & 0.390603 & 8.649845 & 0.0000 \\
$\quad$ Employment & -0.969221 & 0.074056 & -13.08764 & 0.0000 \\
\hline \hline Rtock & 0.909767 & Mean dependent var & 4.634215 \\
R-squared & 0.903945 & S.D. dependent var & 0.549696 \\
Adjusted R-squared & 0.170366 & Akaike info criterion & -0.617639 \\
S.E. of regression & 0.899761 & Schwarz criterion & -0.482960 \\
Sum squared resid & 13.49987 & F-statistic & 156.2766 \\
Log likelihood & 1.168300 & Prob(F-statistic) & 0.000000 \\
Durbin-Watson stat & & &
\end{tabular}

Table A2: $\quad$ Short Run Model

Sample (adjusted): 1991S2 2007S2

Included observations: 33 after adjustments

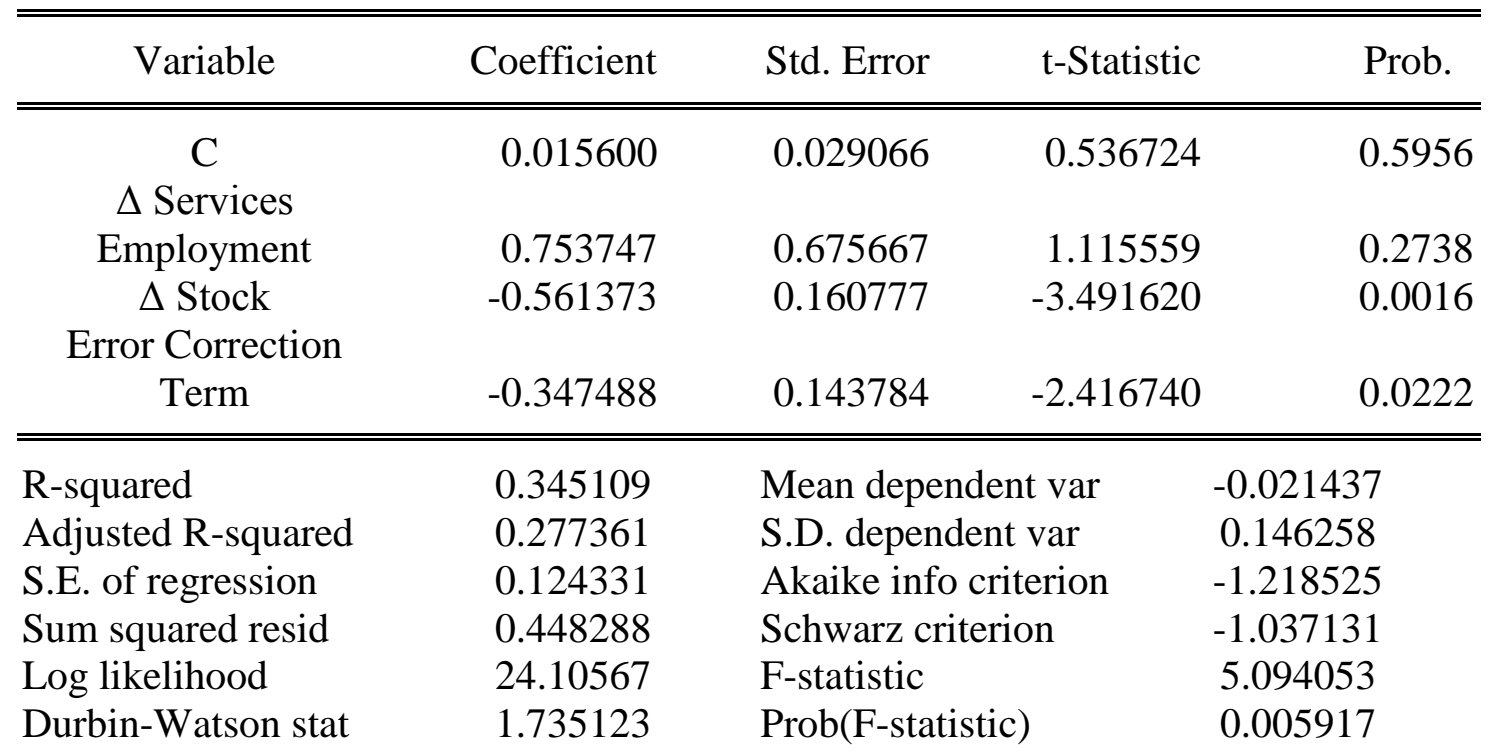

